\title{
Analysis of Affecting Factors on IFRS Adoption:Case Study in Iran
}

\author{
Mehrnaz Paknezhad ${ }^{1, *}$ \\ ${ }^{1}$ Faculty of Accounting, Payam-e- Noor University, Zanjan, Iran \\ *Correspondence: Faculty of Accounting, Payam-e- Noor University, Zanjan, Iran. E-mail: mehrpkd@gmail.com
}

Received: January 11, 2017 Accepted: January 21, 2017 Online Published: January 25, 2017

doi:10.5430/mos.v4n1p74 URL: http://dx.doi.org/10.5430/mos.v4n1p74

\begin{abstract}
IFRS adoption is mandatory for countries such as EU (Europe Union) listed countries while is voluntary for some countries like Iran. But because the adoption benefits cannot be ignored, Thus, as the main objective of our paper, the effect of some factors on the International Financial Reporting Standard (IFRS) adoption is been considered for analysis Therefore, Statistical population of this research is financial business managers and experts of company listed on the Tehran Stock Exchange. This research with regard to objective is practical and with regard to research design is descriptive survey, regarding the level of variable measurement, Pearson correlation test was used for the analysis of relationship between variables and regression analysis was used for analysis of type and form of relation. The results of analysis show that there is a meaningful relationship between of some affecting factors and IFRS adoption in Iran.
\end{abstract}

Keywords: IFRS adoption; affecting factors; voluntary adoption

\section{Introduction}

International Financial Reporting Standards (IFRS), a set of accounting standards referred to by the International Accounting Standards Board (IASB) have been developed. International Accounting Standards Board (IASB), an independent body based in London, which has 15 members from various countries and his work from 2001 has begun. The delegation established by the big accounting firms, private financial institutions and a number of other professional organizations in the field of accounting is done.The purpose of these standards, preparation of financial statements of corporations in the form of a global standard.With the adoption of IFRS, the financial statements of a company with foreign competitors provide similar principles.The application of IFRS could increase foreign investment for companies that want their own benefit. The application of IFRS standards in some countries is mandatory and some voluntary. In Iran, according to the movement toward creating international capital markets, the stock exchange intends to use this standard of 2017 years in the executive stock companies.

\section{Literature Review}

Studies examining analysts' earnings forecasts pre-and post-IFRS adoption are categorized by Bruggeman et al (2012) as providing indirect evidence of capital-market effects associated with an accounting regime change. Beaver (1998) found that financial analysts are regarded as important information intermediaries in capital markets because they provide investors with future earnings forecasts.Dask et al (2008) found that the IFRS adoption capital -market effects were the strongest among the European Union (EU) countries, compared to other nations. Nevertheless, the authors acknowledge that this result can be attributed EU. Bradbery and Van Zijl (2006) suggest that firm size is an important factor impacting on IFRS adoption. This is due to larger firms having greater ability to absorb the cost of adoptions and because the various advantages of IFRS adoption would outweigh the disadvantages. Capon et al (2012) found that voluntary adoption by firms pre-2005 decreased instances of earnings management, as often those firms adoption IFRS to increase transparency in order to attract investors and externa.l capital.Hong (2000) using a large sample of firm year observation across 21 country, finds that there is a negative relation between accrual accounting and the value relevance of financial statements in countries with weak investor protection regime. Dask et al (2008) point out that the capital market benefits occur only in countries with strong enforcement regimes and in countries where the institutional environment provides strong incentives to firm to be transparent.Zeff (1978) defines economic consequences as "the impact of accounting reports on the decision making behavior of business, government, unions, investors and creditors". 
Li (2009) focuses on the impact of IFRS on the implied cost of equity capital, derived from analyst - forecast earnings and stock prices. Alsuhaibani (2012) found that the experience of countries who adopter who are considering the adoption of IFRS show that such adoption is expected to impact many aspects including regulation , regulating bodies, systems, processes, financial outcomes, education, and people. Chebaane and Ben Othman (2014) show that in an emerging economy with a high level of external economic openness, a strong investor protection, a full protection of minority shareholders and with sophisticated capital market, the level of firms' value relevance is more pronounced. Zehri and chouaibi (2013) found that the developing countries most favorable to the adoption of IFRS are those having a high economic growth rate, an high level of education and common law based a legal system. Procha'zka and Pela'k (2015) conclude that voluntary IFRS adopters have strong incentives to communicate with public in a transparent manner, including the extended voluntary disclosures and timely recognition of bad news. The transparency is in turn appreciated by investors. The achievement of benefits (lower cost of capital, foreign analysts' following; etc) by companies, which made a credible voluntary commitment to adopt high quality standards, such as IFRS, is then of endogenous nature and self-explaining.

In one of the first large scale studies of firms adopting IFRS in a mandatory setting, Daske et al (2008) conclude that market liquidity increases following introduction of IFRS. They also find evidence of a decrease in firms' cost of capital and an increase in equity value occurring prior to the official adoption date. Li (2010) finds IFRS mandatory adopters benefit through reduced cost of capital in the immediate mandatory adoption period, reflecting increased disclosure and enhanced information comparability. Platikanova and Perramon (2012) argue that "the quality of information is high if users are able to identify similarities in and differences between two sets of economic phenomena", referring to the fact that IFRS "is proposed to eliminate informational externalities arising from lack of comparability. Pa'scan (2015) suggest that in order to achieve the intended benefits of IFRS adoption, related to increased comparability and transparency of financial reporting IFRS application should result in improved quality of accounting information. Ahmed et al (2013) show that vale relevance of book value of equity and earnings are statistically significant in both pre-and post-IFRS periods and the association is affected by legal origin, accounting and auditing enforcement, congruency between domestic GAAP and IFRS, and model of adoption ( voluntary versus mandatory ). Kim (2016) find the obvious similarity between the IFRS adoption experience of Russian market and the EU markets, for instance, in that the IFRS adoption was one change in the pool of capital market reforms intended to improve reporting quality and lower information asymmetry for investors.Houqe et al (2016) find a significant negative association between IFRS adoption and the cost of equity capital.

\section{Methodology}

This research is applied regarding objective and with regard to research design is descriptive survey. The objective of applied research is to develop applied knowledge in a particular field. In other words, applied research leads to scientific application of knowledge. And descriptive research includes a collection of methods whose aim is to describe conditions with phenomena under study. Implementing descriptive research can only be for the purpose of more familiarity with present conditions or voting to decision making process. Most of researches in behavioral science can be considered as descriptive research. The main objective of our paper, the effect of some factors on the International Financial Reporting Standard (IFRS) adoption is been considered for analysis. These factors are; Economic growth, The educational level, The legal system, Foreign financial communication that are been explained as follow.

\subsection{Research Hypotheses}

3.1.1 There is a significant relation between economic growth and IFRS adoption

3.1.2 There is a significant relation between educational level and IFRS adoption.

3.1.3 There is a significant relation between legal system and IFRS adoption.

3.1.4 There is a significant relation between foreign financial communication and IFRS adoption.

\subsection{Statistical Population}

Statistical population of this research is financial business managers and experts of company listed on the Tehran Stock Exchange. Since the statistical population in this research is managers and experts who are divided into two groups of managers and experts, from each class, people are randomly selected, in fact sampling method is categorized. In this research we calculate sample population by Cochran formula. 


$$
n=\frac{\frac{z^{2} p q}{d^{2}}}{1+\frac{1}{N}\left(\frac{z^{2} p q}{d^{2}}-1\right)}
$$

In this formula:

$\mathrm{n}=$ sample population

$\mathrm{N}=$ statistical population that equals to 321 .

Possibility of first type error (a) equals to $5 \%$, as a result $\mathrm{Z}(\mathrm{a} / 2)=1.96, \mathrm{P}=0.5$ and $\mathrm{q}=0.5$ (relative Community) that is equally determined. The accepted error (d) calculated equals to $5 \%$.

According to this formula, sample population equals to 175. 200 questionnaires were distributed from which 176 questionnaires returned to the researcher flawless and correctly and analysis operation was performed on them. The tools for assessing this research were questionnaire whose questions were posed in two expert group (related to research variables) and demographic group with 33 questions.Questions of expert group evaluate the relationship between each indicator of affecting factors on IFRS adoption.

Table 1. Questions about Research Hypotheses

\begin{tabular}{ll}
\hline Research variables & Questions \\
\hline Economic growth & 1 to 6 \\
Educational level & 7 to 13 \\
Legal system & 14 to 20 \\
Foreign financial communication & 21 to 24 \\
IFRS adoption & 25 to 29 \\
Demographic variables (position, job history, education, information access) & 30 to 33 \\
\hline
\end{tabular}

Questions of this questionnaire were in closed form and in a 5 degree Likert scale and in form of totally agree (5), agree (4), neither agree nor disagree (3), agree (2), totally disagree (1). The questionnaire validity was also assessed. By validity we mean, questions in this questionnaire

examine exactly variables and subject under study, i.e. as much as possible data collected through questionnaire are not more than the researcher's needs and at the same time part of data needed related to assessing variables in examination are not deleted and reality is as it is shown, the amount of circumstantial evidence KMO shows the meaningful level of Kerroit Bartlett. For KMO, amounts lower than 0.5 shows trivial factor analysis, 0.5 to 0.7 shows average factor analysis, 0.7 to 0.8 shows balanced factor analysis, 0.8 and higher shows desirable factor analysis. For the present data amount of KMO obtained, shows a suitable factor analysis.

Table 2. Circumstantial Evidence KMO

\begin{tabular}{llllll}
\hline Variable & $\begin{array}{l}\text { Economic } \\
\text { growth }\end{array}$ & $\begin{array}{l}\text { Educational } \\
\text { level }\end{array}$ & Legal system & $\begin{array}{l}\text { Foreign financial } \\
\text { communication }\end{array}$ & IFRS adoption \\
\hline KMO & 0.73 & 0.66 & 0.60 & 0.77 & 0.73 \\
\hline
\end{tabular}

Reliability of questionnaire was also tested. Reliability refers to accuracy, trustworthiness, stability or being repeatable of test results. To measure questionnaire's reliability, at first a number of 30 Consumers were randomly chosen and after distributing, gathering and analyzing data, questionnaire reliability was calculated using Cronbach alpha for each variable and the entire questionnaire.

Table 3. Reliability Coefficient of Questionnaire

\begin{tabular}{lllllll}
\hline Variable & $\begin{array}{l}\text { Economic } \\
\text { growth }\end{array}$ & $\begin{array}{l}\text { Educational } \\
\text { level }\end{array}$ & $\begin{array}{l}\text { Legal } \\
\text { system }\end{array}$ & $\begin{array}{l}\text { Foreign financial } \\
\text { communication }\end{array}$ & $\begin{array}{l}\text { IFRS } \\
\text { adoption }\end{array}$ & $\begin{array}{l}\text { Total } \\
\text { average }\end{array}$ \\
\hline $\begin{array}{l}\text { Cronbach } \\
\text { alpha }\end{array}$ & 0.61 & 0.72 & 0.73 & 0.76 & 0.79 & 0.87 \\
\hline
\end{tabular}


According to the table above all dimensions have Cronnbach alpha higher than 0.6 and the total average equals to 0.87 that shows desired reliability of questionnaire.

\subsection{Data Analysis}

In this research, in order to analyze data SPSS software version 21 was used. Analysis of research questions was performed at two levels of inferential and descriptive statistics. At the descriptive part, statistical analysis including frequency, percentage is used along with tables and figures. In inferential statistics with regard to the level of variable measurement Pearson correlation test was used for analyzing the relationship between variables and regression analysis was used for analyzing type and form of relationship. Descriptive findings of this research includes frequency table and percentage of individual characteristics of sample people and statistical descriptive indicators like average, standard deviation and variance that if needed for all variables under study is presented in this research.

Table 4. Frequency Distribution According to Job History

\begin{tabular}{lll}
\hline Job history & Frequency & Real percentage \\
\hline Under 10 years & 77 & 43.8 \\
11 to 20 years & 87 & 49.4 \\
Over 30 years & 12 & 6.8 \\
Total & 176 & 100 \\
\hline
\end{tabular}

Findings of table 4 show that 77 people less than 10 years ( 43.8 percent), 87 people ( 99.4 percent) up to 20 years and 12 people (6.8) have over 30 years of job history. Findings of table 5 show that 10.2 percent (18 people) of sample population have diploma, 15.9 percent ( 28 people) have associate degree, 60.2 percent (106 people) have bachelor degree and finally 13.6 percent ( 24 people) have master's degree and higher.

Table 5. Frequency Distribution Based on Respondents' Educational Degree

\begin{tabular}{lll}
\hline Education & Frequency & Real percentage \\
\hline Under diploma & 0 & 0 \\
diploma & 18 & 10.2 \\
Associate degree & 28 & 15.9 \\
Bachelor degree & 106 & 60.2 \\
Master's degree & 24 & 13.6 \\
Total & 176 & 100 \\
\hline
\end{tabular}

\subsection{Hypothesis Testing}

\subsubsection{Testing the First Hypothesis}

First hypothesis states that there is meaningful relationship between primary actions for information security management and success in managing financial information security.

H0: $\rho=0$

$\mathrm{H} 1: \rho \neq 0$

Table 6. Results of Pearson Correlation Test

\begin{tabular}{clll}
\hline \multirow{2}{*}{ Variables } & IFRS adoption & $\begin{array}{l}\text { Correlation } \\
\text { coefficient }\end{array}$ & $\begin{array}{l}\text { Meaningful } \\
\text { level }\end{array}$ \\
\cline { 2 - 4 } & Economic growth & 0.39 & 0.00 \\
\hline
\end{tabular}

As table 6 shows, significance level of correlation test is lower than 0.05 , thus, there are sufficient reasons for rejecting null hypothesis, i.e. there is a significant relationship between independent variable of Economic growth and IFRS adoption; also regarding the fact that the correlation coefficient is positive, the variables are aligned.

3.4.2 Testing the Second Hypothesis

The second hypothesis indicates that there is a significant relationship between Educational level and IFRS adoption. 
H0: $\rho=0$

H1: $\rho \neq 0$

Table 7. Results of Pearson Correlation Test

\begin{tabular}{clll}
\hline Variables & IFRS adoption & $\begin{array}{l}\text { Correlation } \\
\text { coefficient }\end{array}$ & $\begin{array}{l}\text { Significance } \\
\text { level }\end{array}$ \\
\cline { 2 - 3 } & Educational level & 0.77 & 0.00 \\
\hline
\end{tabular}

As table 7 shows, Significance level of correlation test is lower than 0.05 , thus there are enough reasons to reject null hypothesis, i.e. there is a significant relationship between independent variable of Educational level and IFRS adoption; also with regard to the fact that the correlation coefficient is positive, the variables are aligned.

\subsubsection{Testing the Third Hypothesis}

The third hypothesis states that there is significant relationship between Legal system and IFRS adoption.

H0: $\rho=0$

$\mathrm{H} 1: \rho \neq 0$

Table 8. Results of Pearson Correlation Test

\begin{tabular}{llll}
\hline \multirow{2}{*}{ Variables } & IFRS adoption & $\begin{array}{l}\text { Correlation } \\
\text { coefficient }\end{array}$ & $\begin{array}{l}\text { Significance } \\
\text { level }\end{array}$ \\
\cline { 2 - 4 } & Legal system & 0.60 & 0.00 \\
\hline
\end{tabular}

As table 8 shows, significance level of correlation test is lower than 0.05 , thus there are enough reasons to reject null hypothesis, i.e. there is a significant relationship between independent variable of Legal system and IFRS adoption; also with regard to the fact that the correlation coefficient is positive, the variables are aligned.

\subsubsection{Testing the Forth Hypothesis}

The fourth hypothesis states that there is a significant relationship between

Foreign financial communication and IFRS adoption.

H0: $\rho=0$

$\mathrm{H} 1: \rho \neq 0$

Table 9. Results of Pearson Correlation Test

\begin{tabular}{llll}
\hline \multirow{2}{*}{ Variables } & IFRS adoption & $\begin{array}{l}\text { Correlation } \\
\text { coefficient }\end{array}$ & $\begin{array}{l}\text { Significance } \\
\text { level }\end{array}$ \\
\cline { 2 - 4 } & $\begin{array}{l}\text { Foreign financial } \\
\text { communication }\end{array}$ & 0.22 & 0.005 \\
\hline
\end{tabular}

As table 9 shows, significance level of correlation test is lower than 0.05 , thus there are enough reasons to reject null hypothesis, i.e. there is a significant relationship between independent variable of Foreign financial communication and IFRS adoption; also with regard to the fact that the correlation coefficient is positive, the variables are aligned. With regard to the results obtained, we find out that the intensity of correlation between IFRS adoption and Educational level has the highest amount and Foreign financial communication has the lowest amount.

\subsection{Result Analysis}

Determination coefficient is a percentage of dependent variable changes that is indicated by dependent variable, for the present data, since the amount of indicator equals to 0.63 , thus, the model is able to explain 63 percent of changes in affecting factors on IFRS adoption. The remaining percentage is related to other factors that are not studied in this research. Regarding the undesirable effect of entrance of some variables with an insignificant effect, the amount of determination coefficient reduces from 0.62 to 0.61 . 
Table 10. Multiple Correlation Coefficient and Determination Coefficient

\begin{tabular}{lllll}
\hline Model & $\begin{array}{l}\text { multiple } \\
\text { correlation } \\
\text { coefficient }\end{array}$ & $\begin{array}{l}\text { determination } \\
\text { coefficient }\end{array}$ & $\begin{array}{l}\text { Balanced } \\
\text { determination } \\
\text { coefficient }\end{array}$ & $\begin{array}{l}\text { Standard } \\
\text { deviation } \\
\text { method }\end{array}$ \\
\hline 1 & 0.791 & 0.626 & 0.616 & 0.83901 \\
\hline
\end{tabular}

Table 11. Variance Analysis

\begin{tabular}{llllll}
\hline Model & $\begin{array}{l}\text { Total } \\
\text { square }\end{array}$ & df & $\begin{array}{l}\text { Mean } \\
\text { square }\end{array}$ & F & Sig. \\
\hline Regression & 898.783 & 4 & & & \\
Remaining & 537.729 & 159 & 224.969 & 66.440 & 0.0 \\
Total & 1436.512 & 163 & 3.382 & & \\
\hline
\end{tabular}

The above table shows the regression variance analysis. This model includes dependent and independent variables. Since probability of test significance is less than 0.05 , regression model is significant i.e. this model is able to predict dependent variable; in other words at least one of independent variables is effective in predicting dependent variable. So, each independent variable should be tested by T-test.

Table 12. Regression Coefficient

\begin{tabular}{|c|c|c|c|c|c|c|c|}
\hline \multirow[t]{2}{*}{ Model } & \multicolumn{2}{|c|}{$\begin{array}{l}\text { Non-standard } \\
\text { coefficients }\end{array}$} & \multirow{2}{*}{$\begin{array}{l}\text { standard } \\
\text { coefficients }\end{array}$} & \multirow[b]{2}{*}{$\mathbf{t}$} & \multirow[b]{2}{*}{$\begin{array}{l}\text { Sig. } \\
\text { Lower } \\
\text { Bound }\end{array}$} & \multicolumn{2}{|c|}{$\begin{array}{l}95.0 \% \text { Confidence } \\
\text { Interval for } \mathbf{B}\end{array}$} \\
\hline & B & $\begin{array}{l}\text { Std. } \\
\text { Error }\end{array}$ & & & & $\begin{array}{l}\text { Upper } \\
\text { B Bound }\end{array}$ & \\
\hline Y-intercept & -1.815 & 1.098 & & -1.652 & .100 & -3.984 & .355 \\
\hline Economic growth & -.118 & .061 & -.120 & -1.930 & .055 & -.239 & .003 \\
\hline Educational level & .551 & .053 & .675 & 10.382 & .000 & .447 & .656 \\
\hline Legal system & .191 & .048 & .259 & 3.955 & .000 & .096 & .287 \\
\hline $\begin{array}{l}\text { Foreign financial } \\
\text { communication }\end{array}$ & -.001 & .017 & -.004 & -.083 & .934 & -.035 & .033 \\
\hline
\end{tabular}

In column $\mathrm{B}$, the amount of $\mathrm{y}$-intercept and regression non-standard coefficient was presented; the amount of positive effect of each independent variable on the dependent variable. Beta non-standard coefficient indicates the amount of change in dependent variable per each unit change in independent variable. With regard to the significance probability of test for regression coefficient, y-intersect and Economic growth variables and Foreign financial communication are not significant ( $\mathrm{sig}>0.05)$. Regression coefficient is significant for significance coefficient and Legal system and Educational level ( $\mathrm{sig}>0.05$ ). i.e. per each unit increase in Legal system, 0.26 units increase occurs in success of IFRS adoption and per each unit change in Educational level, 0.67

Units change happens in the success of IFRS adoption.

$Y=0.67 t+0.26 m$

t: Educational level

m: Legal system

Y: IFRS adoption

\section{Conclusion}

In particular, countries with high levels of oil and gas reserves, may wish to attract foreign investment to expedite access to their reserves, leaving to expedite access to these reserves, leading to economic growth. Consequently, these nations would see a need to strengthen their accounting system through IFRS adoption.

In this article, the effect of some factors on the International Financial Reporting Standard (IFRS) adoption in Iran were studied analysis. These factors are; Economic growth, The educational level, The legal system, Foreign 
financial communication. According to results of Pearson correlation test, there is a significant relationship between The above factors and IFRS adoption. The results of Beta coefficient show that there is a meaningful relationship between of The educational level, The legal system and IFRS adoption in Iran.

Other developing economies and nations in the region seeking assistance to strengthen their economies are likely to face pressure to adopt IFRS from powerful global aid organizations where an economy is poor or small; it is more dependent on international aid to meet basic needs. As such, these economies will be subject to the coercive power of a range of non-government organizations seeking to bring about changes through foreign aid, like the Word Bank or the International Monetary Fund .However, the inclusion of non-adopting as control group does not solve the main problem with the selection of affected companies in adopting countries. The transaction from domestic GAAP to IFRS did not happen overnight. A relatively long transitional period provided companies with the opportunities to estimate the impacts of IFRS adoption properly and to accommodate to the changeover.

\section{References}

Ahmed, K.., Chalmers, K., \& Khlif, H. (2013). A Meta- analysis of IFRS Adoption Effects. The International Journal of Accounting, 48, 173-217. https://doi.org/10.1016/j.intacc.2013.04.002

Alsuhaibani, A. (2012). The expected Impact of IFRS Adoption on Saudi Arabia Based on Lessons from other countries: A Focus on Telecommunication Business. Procedia -Social and Behavioral Sciences, 62, 1190-1198. https://doi.org/10.1016/j.sbspro.2012.09.204

Arpen, J.S., \& Radebaugh, L, H. (1985). International Accounting and Multinational Enterprising. New York: Wiley.

Ball, R., S. Kothari, \& A. Robin. (2000). The Effects of International Institutional Factors on properties of Accounting Earnings. Advances in International Accounting, 8, 87-97. https://doi.org/10.1016/s0165-4101(00)00012-4

Bradbury, M., \& Zijl, T. (2006). Due process and the Adoption of IFRS in New Zealand. Australian Accounting Review, 16(39), 86-94. https://doi.org/10.1111/j.1835-2561.2006.tb00363.x

Bruggeman, U., Hitz, J., \& Sellhom, T. (2012). Intended and unintended consequences of mandatory IFRS adoption: Areview of extant evidence and suggestion for future research. Retrieved from http://ssm.com/abstruct=1684036.http://dx.doi.org/10.2139/ssrn.1684036

Bruggemann , U., Hitsz, J.-M., \& Sellhorn,T. (2013). Intended and unintended consequences of Mandatory IFRS Adoption: A Review of Extant Evidence and Suggestions for future Research. European Accounting Review, 22, 1-37. https://doi.org/10.1080/09638180.2012.718487

Burgstahler, D. C., Hail, L., \& Leuze, C. (2006). The Importance of Reporting Investments: Earnings Management in European Private and Public Firms. The Accounting Review, 81, 983-1016. https://doi.org/10.2308/accr.2006.81.5.983

Capkun, V., Collins, D.W., \& Jeanjean, T. (2012). Does Adoption of IAS/IFRS Deter Earnings Management? Working paper. Retrieved from http://ssrn.com/so13/papers.cfm?abstract_id=1850228

Chebaane, S., \& Ben Othman, H. (2014). The impact of IFRS adoption on Value relevance of earning and book value equity: the case of emerging markets in African and Asian regions. Procedia - Social and Behavioral Sciences, 145, 70-80. https://doi.org/10.1016/j.sbspro.2014.06.012

Chiu, T.T., \& Lee,Y.J. (2013). Foreign private Issuers' Application of IFRS Application of IFRS Around the Elimination of the 20-F Reconciliation Requirement. The International Journal of Accounting, 48, 54-83. https://doi.org/10.1016/j.intacc.2013.01.006

Cooke, T., \& Wallace, O. (1990). Financial disclosure regulation and its environment: A review and analysis. Journal of Accounting and Public Policy, 9(2), 79-110. https://doi.org/10.1016/0278-4254(90)90013-P

Covrig, V., Defond, M., \& Hung, M. (2007). Home bias, foreign fund holdings, and the voluntary adoption of International Accounting standards. Journal of Accounting Research, 45(1), 41-70. https://doi.org/10.1111/j.1475-679X.2007.00226.x

Daske, H., Hail, L., Leuz, C., \& Verdi, A. (2008). Mandatory IFRS Reporting around the world:Early Evidence on the Economic consequences. Journal of Accounting Research, 40(5), 1085-1142. 
Doupnik, T., \& S. Salter. (1995). Eternal Environment, culture, Accounting practice: A preliminary Test of a General Model of International Accounting Development. The International Journal of Accounting, 30, 189-207.

Gordon, R.H., \& Bovengerg, A.L. (1996). Why is capital so Immobile Internationally? Possible explanations and implications for capital income taxation. The American Economic Review, 86, 1057-1075.

Houqe, M. N., Monem, R, M., \& Zijl, T. V. (2016). The Economic consequences of IFRS adoption: Evidence from New Zealand. Journal of International Accounting, Auditing and Taxation, 27, 40-48. http://dx.doi.org/doi:10.1016/j.intaccaudtax.2016.10.001

Hung, M. (2000). Accounting standards and valu relevance of financial statement: An international analysis. Journal of Accounting and Economics, 30(3), 401-420. https://doi.org/10.1016/S0165-4101(01)00011-8

Judge, W., Li, S., \& Pinsker, R. (2010). National adoption of International Review, 18(3), 161-174.

Kim, O. (2016). The IFRS Adoption Reform through the lens of Neo institutionalism: The case of the Russian Federation. The International Journal of Accounting, 51(3), 345-362. https://doi.org/10.1016/j.intacc.2016.07.001

La pota, R., F. Lopez-de Silanes, A., Sheifer \& R. Vishny. (1997). Legal Determinants of External Finance. The Journal of External Finance, 52(3), 1131-1150. https://doi.org/10.1111/j.1540-6261.1997.tb02727.x

Li, S. (2010). Does mandatory adoption of International Financial Reporting Standards in the European Union reduce the cost of equity capital? Accounting Review, 85(2), 607-636. https://doi.org/10.2308/accr.2010.85.2.607

Li, X. (2009). Accounting conservatism and cost of capital; International analysis. Available at SSRN http://ssrn.com/abstract $=1261971$

Pascan, I. D. (2015). Measuring the effects of IFRS adoption on accounting quality: a review. Procedia Economics and Finance, 32, 580-587. https://doi.org/10.1016/S2212-5671(15)01435-5

Platikanova, P., \& Perramon, J. (2012). Economic consequences of the first -time IFRS introduction in Europe. Revista Espanola de Financiaon Y Contabilidad, XLI(156), 497-519. https://doi.org/10.1080/02102412.2012.10779733

Prochazka D., \& Prochazkova Ilinitchi, C. (2011). The Theoretical Relationships among Foreign Direct Investments; Migration and IFRS adoption. European Financial and Accounting Journal, 6, 85-100. https://doi.org/10.18267/j.efaj.21

Prochazka, D., \& Pelak, J. (2015). The Development of capital Markets of New EU countries in the IFRS Era. Procedia Economics and Finance, 25, 116-126.

Skinner, D. J. (1994). Why Firms Voluntarily Disclose Bad News. Journal of Accounting Research, 32, 38-60. https://doi.org/10.2307/2491386

Street, D. L., \& Larson, R. K. (2004). Large accounting firms' survey reveals emergence of "Tow Standard" system in the European Union. Advances in International Accounting, 17. https://doi.org/10.1016/S0897-3660(04)17001-3

Vasek, L., \& Gluzova, T. (2014). Can a new concept of control under IFRS have an Impact on a CCCTB? European Financial and Accounting Journal, 9, 110-127.

Wooly, R. (1998). International accounting standards and economic growth, an empirical investigation of their relationship in Asia. Working Paper series Australia: School of Accounting and Law, RMIT.

Zeff, S. (1978). The rise of economic consequences. The Journal of Accounting, 146, 56-63.

Zeghal, D., \& Mhedhbi, K. (2006). An analysis of the factors affecting adoption of international accounting standards by developing countries. The International Journal of Accounting, 41, 373-386. https://doi.org/10.1016/j.intacc.2006.09.009

Zehri, F., \& Chouaibi, J. (2013). Adoption determinants of the International Accounting Standards IAS/IFRS by the developing countries. Journal of Economics, Finance and administrative Science, 18, 56-62. https://doi.org/10.1016/S2077-1886(13)70030-1 